\title{
Notes on some Species of Cladophora from South Africa.
}

\author{
By
}

R. H. Simons.

Several species of Cladophora have been collected during an investigation of Cape seaweeds and most have been readily identified by comparison with named specimens in the Stephenson and Tyson collections of South African seaweeds at the University of Cape Town. Most of Stephenson's material was identified by himself, but it includes some specimens named by overseas authorities. The type specimens of certain species that have particularly interested me are in the Agardh Herbarium in Lund and are not available on loan, which has meant falling back largely on literature for checking identifications. In general, the determination of Cladophoras by these methods has given little dificulty. But there is confusion in the application of the names C. flagelliformis, $C$. capensis and $C$. virgata, and the present paper attempts to resolve the difficulty.

The Tyson specimens under these three names were determined by G. F. Papenfuss in 1939. whereas the Stephenson material was apparently named when collected about 1937. It was obvious that most of Stephenson's specimens of C. flagelliformis and $C$. virgata did not correspond respectively in morphology with specimens so named by Papenfuss in the Tyson collection. The following paragraph was found in a paper by Stephenson (1944) and accounts for this discrepancy: "There are two common species of Cladophora, quite distinct in appearance, which bear these names [C. flagelliformis and $C$. virgata]. One of them is a long, coarse, blue-green species, the other a shorter, silkier, bright green form. The former has hitherto been known as flagelliformis, the latter as virgata. It now proves that the two names should be interchanged, so that the coarse plant becomes virgata, the other flagelliformis". Once the suggested interchange of names had been made in Stephenson's material the discrepancy between this and Papenfuss's (Tyson collection) was removed.

This should have resolved any further difficulty in identifying specimens of these two species, but instead I found that according to the original literature $C$. flagelliformis and $C$. virgata are closely similar, whereas in the material at hand there was a likeness between plants named $C$. flagelliformis and some of those named $C$. capensis, but a dissimilarity between those named $C$. flagelliformis and $C$. virgata.

On comparing the literature on $C$. flagelliformis, it was found that the plants so named in the Stephenson and Tyson collections disagreed in several respects with the original description but agreed with the description given by Levring (1938), thus suggesting that Levring, Papenfuss and Stephenson (after his correction) had misapplied the name.

Stephenson stated that $C$. flagelliformis and $C$. virgata are "quite distinct in their appearance". This is contrary to the views of Kützing (1843), who transferred these species to Cladophora, and of de Toni $(1889$, p. 331). Kützing related the two species closely but stated that $C$. flagelliformis is longer and more slender than $C$. virgata and de Toni added that they are "scarcely distinct". Areschoug (1851) goes further and says they are synonymous. Moreover, Kützing and Stephenson disagree as to which is the longer species, for Stephenson stated that this is C. virgata. 
If a general comparison of Kützing's description of $C$. flagelliformis is made with Stephenson's material under the name $C$. virgata a conformity is immediately apparent. Both have shorter and more slender branches in the lower parts and longer flagelliform branches above. The dilation of all branches towards their apices is characteristic of both, and cell proportions in comparable parts are essentially the same. The apical cells in both are obtuse. de Toni (1889) gives the length of $C$. flagelliformis as $18-20 \mathrm{~cm}$; plants of Stephenson's $C$. virgata are up to $17 \mathrm{~cm}$ long. Several specimens of comparable material collected by me are more than $20 \mathrm{~cm}$. in height, whereas $C$. flagelliformis sensu Levring has a maximum height of $15 \mathrm{~cm}$. The similarity of $C$. virgata sensu Stephenson to the true $C$. flagelliformis (Suhr) Kütz. therefore seems obvious. If Suhr's (1840) original description of flagelliformis is also considered, one sees its applicability to Kützing's figure (Kützing, 1853) of C. virgata (Ag.) Kütz. One is thus led to the hypothesis that Kützing's $C$. flagelliformis is merely a longer form of his C. virgata.

My observations of Cladophora plants in which all the branches dilate upwards, show that there are stunted forms and elongated ones which I am unable to distinguish on morphological grounds as distinct species. The stunted forms in my opinion are typical of $C$. virgata (Ag.) Kütz., and the elongated forms could be referred to $C$. flagelliformis (Suhr) Kütz. Apart from Levring's account of $C$. flagelliformis I can find nothing in the earlier descriptions to show any inherent difference between $C$. virgata and C. flagelliformis except one of relative size, and Kützing's implication of an associated distinction in branching. My observations are that the branching habits of smaller and larger plants show no consistent difference such as that suggested by Kützing.

Stephenson's material named C. flagelliformis on the basis of Levring's description diverges too far from earlier descriptions to be accepted as this species; but in my opinion it is clearly related to Cladophora capensis (Ag.) Kütz. and the two appear to me to be included in the range of variation of one species.

The conclusion reached is that $C$. flagelliformis (Suhr) Kütz. is a synonym of C. virgata (Ag.) Kütz., the latter being the prior name by which the species should be known. $C$. flagelliformis sensu Levring is I suggest a synonym of $C$. capensis (Ag.) Kütz.* A third species $C$. isaacii, identified by an earlier investigator as $C$. capensis, is distinguished.

Descriptions are appended of the three species that have been recognised.

(1) Cladophora virgata (Ag.) Kütz., Sp. Alg. p. 388, 1843.

Conferva virgata Ag., Syst. Alg. p. 119, 1824.

Cladophora flagelliformis (Suhr) Kütz., Sp. Alg. p. 388, 1843.

Holdfast a rather small knob-like structure which is somewhat flattened at its base to form a disc up to $3 \mathrm{~mm}$ in diameter. The whole is formed from the compacting of the main filaments at their bases and is surrounded by a hyaline sheath which is continuous with the walls of the filaments (Fig. 1a). The compact holdfast is not easily dissected owing to the presence of the sheath. Erect System, (i) Branching: Several closely compacted filaments arise from the holdfast and these soon diverge to form elongated filaments which produce short branches almost throughout their length. These short branches diverge strongly from the line of the main filaments and are usually naked (Fig. 1b). Elongated branches arise occasionally in the lower parts, but are mostly

* Dr. Papenfuss has kindly confirmed in a private communication that $C$. virgata (Ag.) Kütz. and $C$. flagelliformis (Suhr) Kütz. are synonymous. He states that the material seen and described by Levring was wrongly circulated by Suhr as examples of Conferva flagelliformis Suhr, but is in fact representative of a new species. At the moment I am not convinced that $C$. flagelliformis sensu Levring is a new species. 
produced in the upper parts; the upper branches may again branch in a di- or trichotomous manner in which case they are all flagelliform (Pl. 1). Branching throughout the plants is typically opposite but may be alternate or in whorls of three or four. All branches dilate towards their apices. Many of the flagelliform branches become truncate by loss of their terminal portions. Basal cells of branches tend to coalesce slightly at their origins but never appear to arise from the centre of a cell, except perhaps near the holdfast. (ii) Cells of the Filaments: Near the holdfast these are clearly defined and are two to four times longer than broad but may occasionally be as much as six times as long as their diameter. In the upper parts all the cells have more or less the same length and breadth (Fig. 1c). The cell contents throughout the plant are dense and opaque, and specimens regarded as comparable in the field are very dark green with a bluish shade. Apical cells of branches have obtuse tips and are usually more or less umbonate (Fig. 2).

(2) Cladophora capensis (Ag.) Kütz. Sp. Alg. p. 421, 1849.

Conferva capensis Ag., Syst. Alg. p. $118,1824$.

Cladophora ecklonii (Rud.) Kütz., Phyc. Gen. p. 270, 1843.

Conferva ecklonii Rud., Linnaea 6, p. 180, 1831; Suhr, Flora 17, p. 741. 1834.

Holdfast: This is a matted cushion up to $1.5 \mathrm{~cm}$. in diameter and formed of branched rhizoids which usually contain chlorophyll. The plant is easily dissected into main filaments with rhizoids below (Fig. 3). Erect System, (i) Branching: This ranges from near dichotomy (Fig. 4) to distinct main filaments bearing fascicles of short branches throughout their length (Pl. 2). Generally branching is alternate, but sometimes the branches arise in whorls of two or more. Longer branches characteristically arise in the lower parts of the plants, but they may occur in the upper parts in which case they may become somewhat dilated and frequently dissolute towards their apices (Fig. 5a). Such dilation frequently results in these branches becoming thicker than the main filaments in their lower parts. The ultimate branchings are often dichotomous. Other branches taper gradually towards their apices (Fig. 5b). Basal cells of branches tend more or less markedly to coalesce with cells of parent filaments (Fig. 5c) especially in the lower parts of the plants where basal cells of branches appear to originate from the centre of a cell, (Fig. 5d). All branches tend to be appressed to their parent filaments (P1. 2). (ii) Cells of the Filaments: Cells near the holdfast are four to six times longer than they are broad but may be up to ten times longer. In the upper parts of the plants the cells are two to four times longer than broad but may be almost as broad as they are long in branches which dilate upwards. Apical cells vary somewhat in shape but they are usually two to three times longer than broad and either umbonately acute. especially in dilated branches (Fig. 5e \& f), or more or less azuminate (Fig. 6). The hyaline cap terminating branches is always thick and may be as much as eight times thicker than the lateral walls. A feature nct always apparent is the presence of inflated cells of a clavate or fusiform shape scattered throughout the length of the plant. Some branches may consist of one or two such cells (Fig. 7).

Plants of this species may be up to $15 \mathrm{~cm}$ high, but if growing in habitats where they are uncovered at low tide and subject to strong wave action they are generally shorter with a strong tendency towards the dichotomous habit. Such plants tend to be more robust and less branched than those growing in pools. Specimens with a fasciculate habit are reminiscent of Kützing's (1854) figures of $C$. neesiorum, $C$. humilis and $C$. ramosissima, all of which de Toni (1889) regards as synonymous. Cladophora capensis is, however, coarser than $C$. neesiorum.

Levring (1938) and Papenfuss (1940) have stated that $C$. capensis and C. ecklonii are synonymous. In my opinion, $C$. flagelliformis sensu Levring is also the same species. 


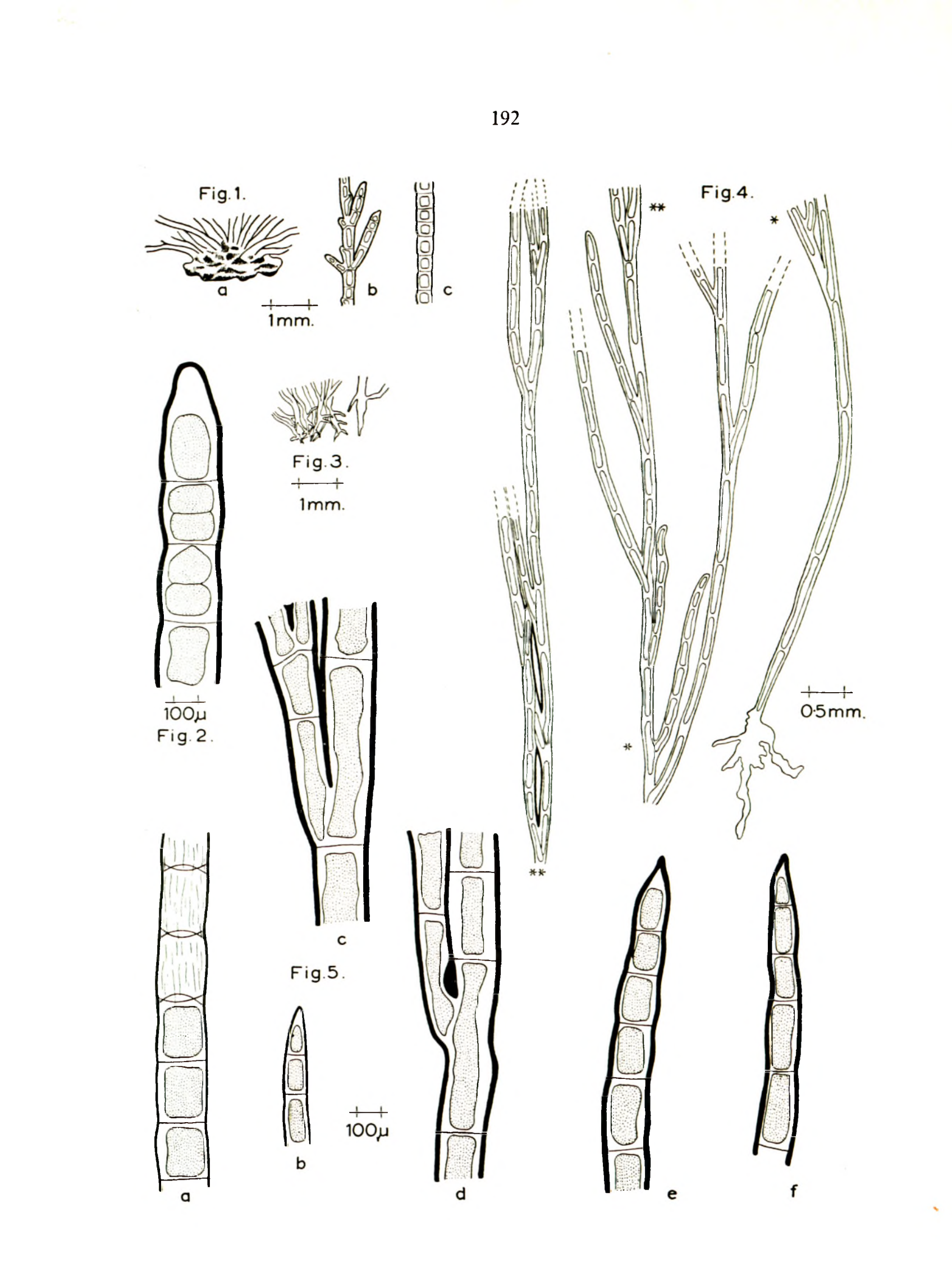



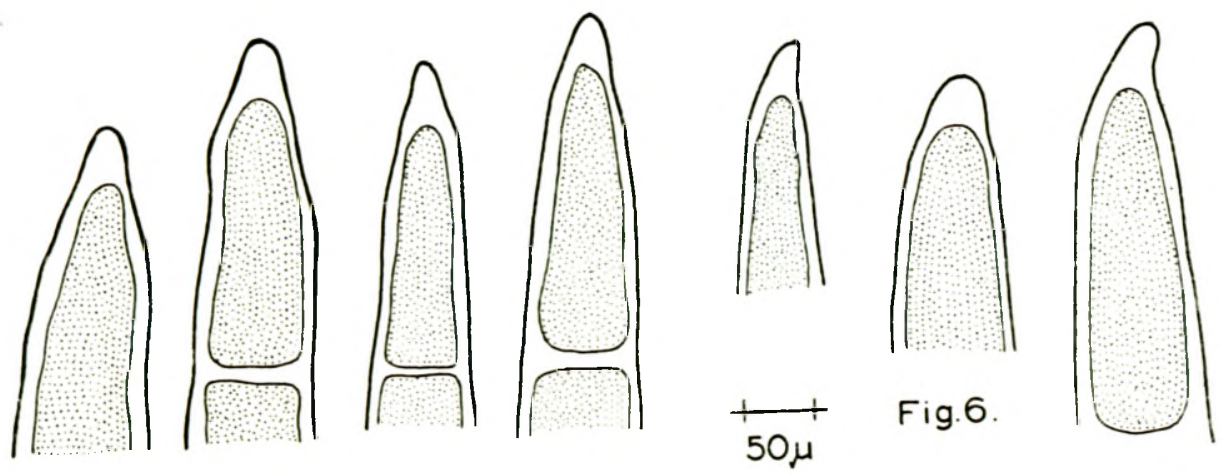

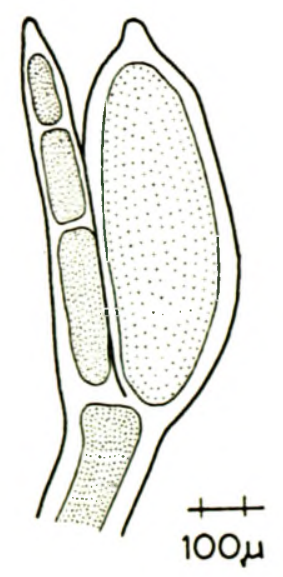

Fig.7.

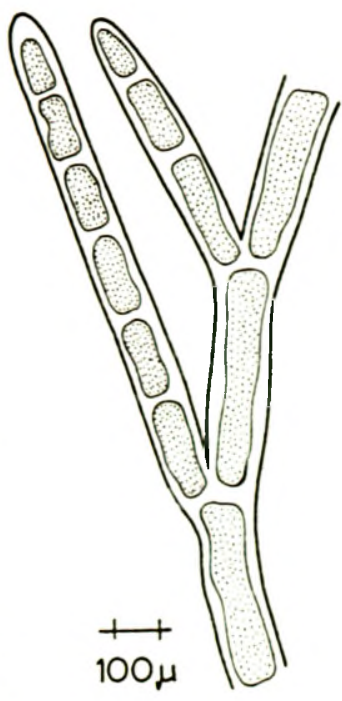

Fig. 8 .
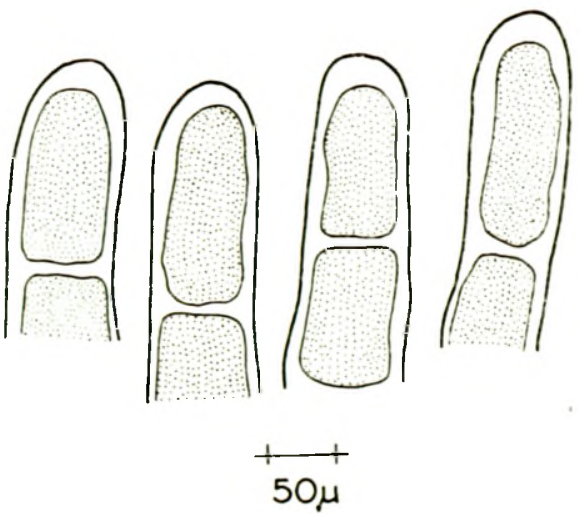

Fig. 9 .

Fig. 1.-C. virgara (Ay.) Kütz. $a$, Hyaline disc forming holdfast; $b$, Short divergent naked branchlets; $c$, Cells near apex of branch.

Fig. 2.-Terminal portion of a branch of $C$. virgata (Ag.) Kütz. showing the obtuse tip of the apical cell.

FIG. 3.- Rhizoids at the base of the main filaments of $C$. capensis (Ag.) Kütz.

Fig. 4.-Near dichotomy of branches of $C$. capensis (Ag.) Kütz.

FIG. 5.-C. capensis (Ag.) Kütz. $a$, Dilated branch with dissolute terminal portion; $b$, Tapering branch with subacuminate tip; $c$, Coalescence of basal cell of branch with parent filament in upper portion of plant; $d$, Basal cell of branch in lower portion of plant; $e$ and $f$, Apices of dilated branches.

FIG. 6.-Forms of apical cells in C. capensis (Ag.) Kütz.

FIG. 7.-Branchlet consisting of a single inflated cell in C. capensis (Ag.) Kütz.

FIG. 8.-Short divergent branches of $C$. isaacii sp. nov.

FIG. 9.-Bluntly rounded apices of branches of $C$. isaacii sp. nov. 


\section{(3) Cladophora isaacii sp. nov.}

Thallus erectus usque ad $40 \mathrm{~cm}$ altus, colore olivaceo-viride; fila primaria inferne ad $200 \mu$ lata; ramis elongatis, ordine tertia quoquoversum ramosis; ramulis ultimis brevioribus, gracilioribus, subdivaricatis usque ad $80 \mu$ latis, quoquoversum vel subsecundo exeuntibus; filis omnibus apices versus vix attenuatis; apicibus obtusis, rotundatis quam muris lateralibus usque ad 3-plo crassioribus incrassatis; cellulis inferioribus diametro 2-6-plo, superioribus 2-3-plo longioribus.

Holdfast: is formed of tightly interwoven rhizoids with dense contents of a dark green colour when fresh. The whole is not more than about $4 \mathrm{~mm}$ in diameter and is frequently higher than it is wide. There is no hyaline sheath surrounding the holdfast but closely appressed decurrent rhizoids arise from the lowest branches of the primary filaments resulting in some matting together of the main filaments below. Erect System, (i) Branching: Branches arise more or less spirally or sometimes oppositely and the ultimate branchlets are frequently short and divergent from the parent filaments (Fig. 8). There is a tendency for branchlets to arise in a secund manner ( $\mathrm{Pl}$. 3), especially in the upper parts. Almost all branches taper slightly towards their tips. Main filaments and primary branches are elongated and end in a comparatively long naked portion which also tapers slightly to the apex. Some specimens have main filaments which branch furcately in their ultimate portions. These branches may become somewhat dilated upwards. Basal cells of elongated primary branches tend to coalesce with the parent filament and may appear to arise from the centre of a cell. (ii) Cells of the Filaments: In the basal parts these are four to six times longer than broad, and two to three times longer than broad higher up. In branches that dilate somewhat, the cells may be almost as broad as they are long. Such cells have denser contents than other filament cells and sometimes have become hyaline due to loss of contents, an occurrence presumably associated with reproduction. The apical cells of branches almost always have bluntly rounded tips and are scarcely narrower than their subterminal cells (Fig. 9).

Specimens of this species which I have found occurred typically in pools at about mid-tide level or higher and have been up to $25 \mathrm{~cm}$ in height. Some plants in the Tyson collection, which I consider to be the same species, are as much as $40 \mathrm{~cm}$ high. In the past this species has been mistaken for $C$. capensis. Its main differences from the latter species are given below.

\section{Comparison of the Three Species.}

C. virgata is easily identified by its bluish-green colour, its disc holdfast and its branching habit, the branches usually being opposite or whorled with all branches dilating upwards and terminating in distinctive umbonately thickened apices. On the other hand, $C$. capensis and $C$. isaacii are much more similar in appearance and more likely to be confused. The main differences are seen in their branching habits. In $C$. capensis the branching is variable but the branchlets tend to be closely appressed to the parent filaments and taper gradually to rather acuminate apices with relatively thick end walls. The apical cell becomes more rapidly narrow towards its tip. In C. isaacii the shorter branches diverge from the parent filaments and all branches taper very little to bluntly rounded apices, whose end walls are thin in comparison with those of $C$. capensis. Moreover the apical cells of the latter species are longer relative to their breadth than those of $C$. isaacii. Inflated cells, scattered throughout the length of the plant, are common in $C$. capensis but have not yet been observed in $C$. isaacii. Plants of $C$. capensis are coarser than those of $C$. isaacii in the upper parts (cfr. Plates $2 \& 3$ ) and are generally much more rigid. The colour of the latter species is an olive green whereas $C$. capensis is a bright green. A further distinction is apparent in that C. capensis in drying sticks to paper only slightly but $C$. isaacii adheres well. 
SUMMARY.

It is shown that $C$. virgata (Ag.) Kütz. and $C$. flagelliformis (Suhr) Kütz. are synonymous, the former being the correct name. The account of $C$. flagelliformis by Levring (1938) is discussed and shown to refer to material not conforming with this species. It is suggested that $C$. flagelliformis in the sense used by Levring, Stephenson and Papenfuss (Tyson collection) is synonymous with C. capensis (Ag.) Kütz. A third species, C. isaacii, is discussed and described as new.

\section{LITERATURE CITED.}

Areschoug, J. E. (1851) ...........

DE Toni, J. B. (1889). . . . . . . . . . .

Kützing, F. (1849)............... .

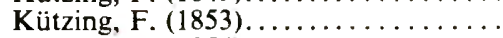

Kützing, F. (1854) .............

LEVRING, T. (1938)............

Stephenson, T. A. S. (1944).

SuHr, J. H. voN (1840).
“Phyceae Capensis", Venia Amplis Philos. Facult. Upsaliensis. p. 9.

"Sylloge Algarum ", Vol. 1, p. 331.

"Species Algarum "', p. 421, Leipzig.

"Tabulae Phyceae", T. 77.

"Tabulae Phyceae", T. 4, 5.

"Verzeichnis Einiger Chlorophyceen und Phaeophyceen von Süd-Afrika", Lunds Univ. Arsskr. N. F. Avd. 2, 34. 9.

"The Constitution of the Intertidal Fauna and Flora of $\mathrm{S}$. Africa, Pt. ii ", Ann. Natal Mus. 10, p. 341.

"Beitrage zur Algenkunde", Flora, 23, p. 294. 


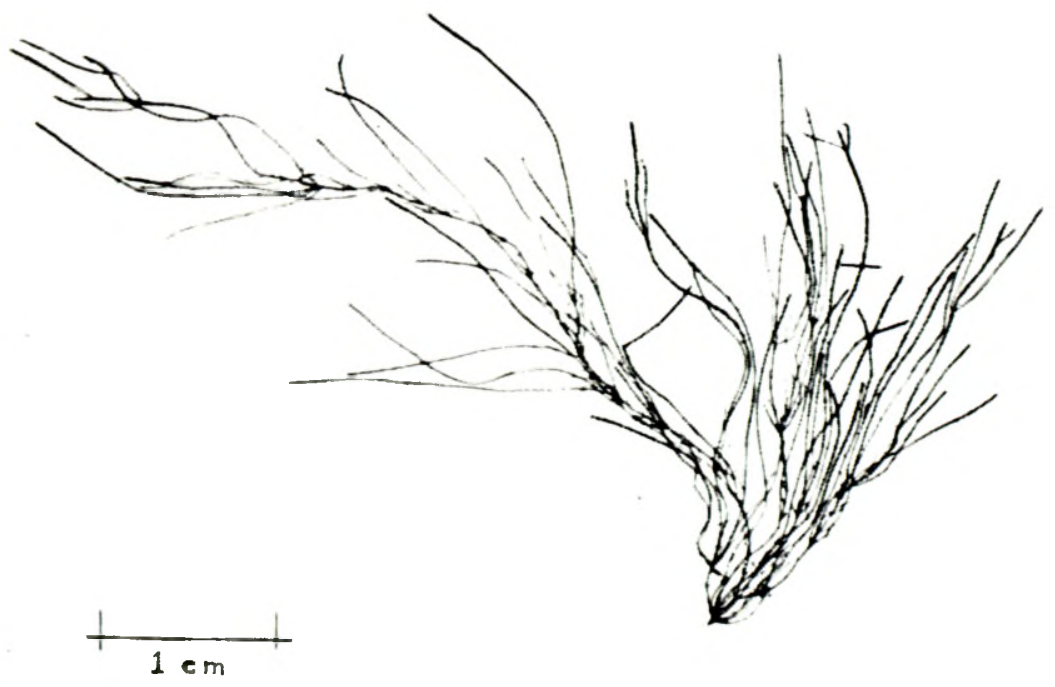

Plate 1.- Habit of upper portion of C. virgata (Ag.) Kütz.. showing elongated flagelliform branches. 


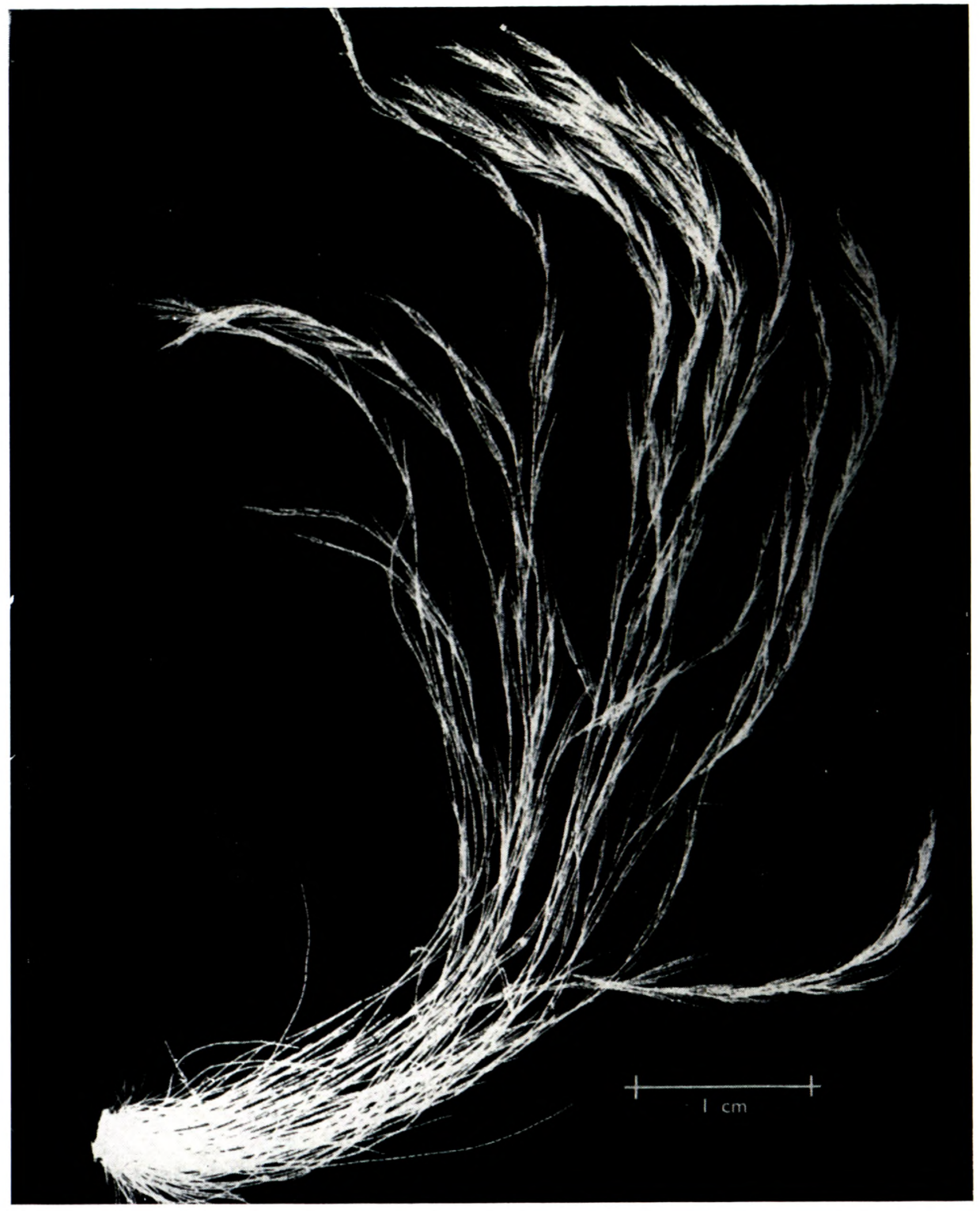

Plate 2.- Habit of some specimens of $C$. capensis (Ag.) Kütz. showing several main filaments bearing fascicles of short branches throughout their length. 


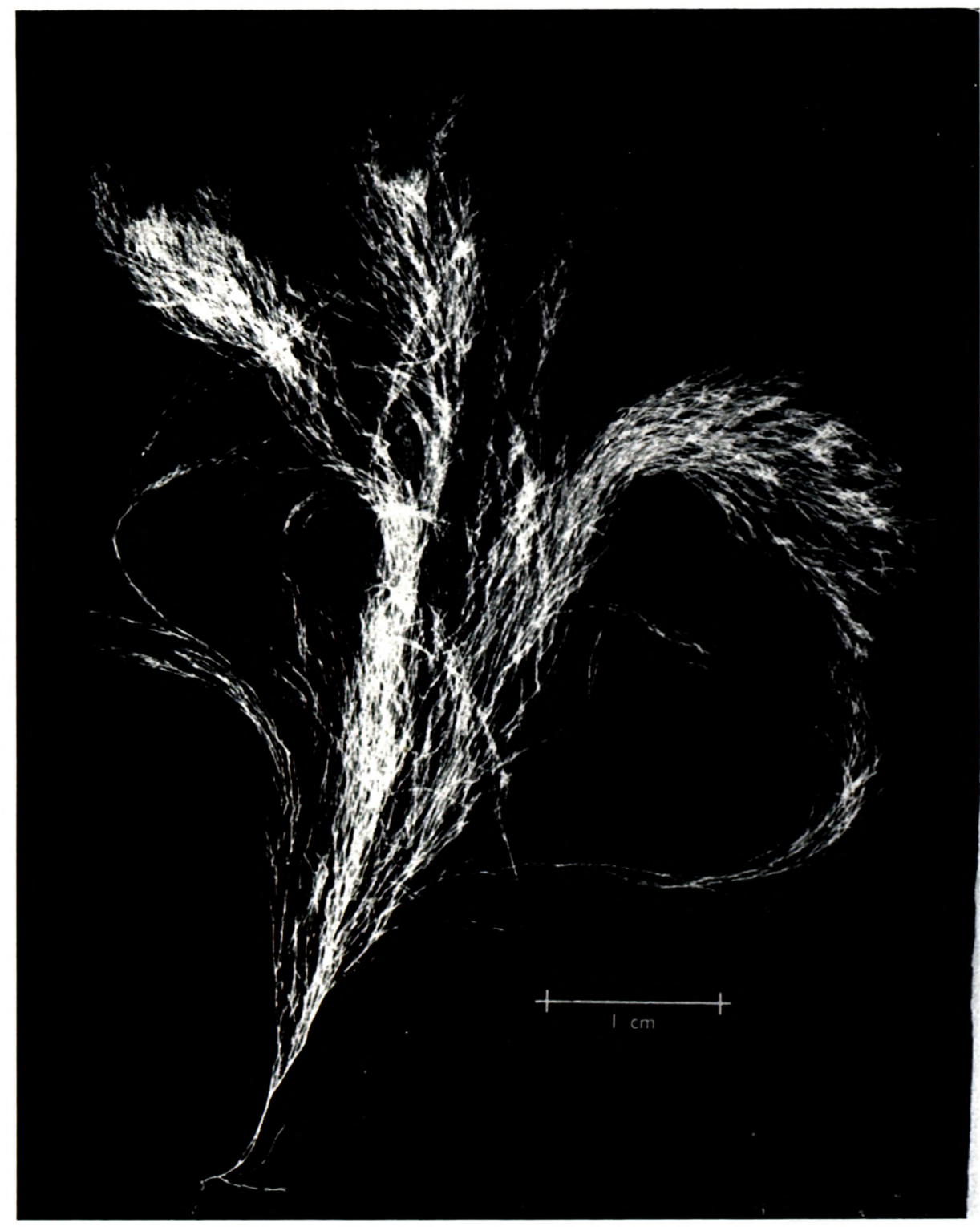

Plate 3.- Habit of C. isaacii, showing secund arrangement of branchlets in upper parts. 
